\title{
THE QUALITY OF THE ENVIRONMENT IN EU COUNTRIES IN RELATION TO GROSS DOMESTIC PRODUCT - STATIC AND DYNAMIC TAXONOMIC ANALYSES ${ }^{1}$
}

\author{
Jan Polcyn², dr hab.; Sebastian Stepien ${ }^{3}$, dr hab. \\ ${ }^{2}$ Stanislaw Staszic University of Applied Sciences in Pila, Poland; ${ }^{3}$ Poznan University of Economics and Business, Poland
}

\begin{abstract}
It is a commonly accepted thesis that the quality of the environment increases together with the level of society's prosperity expressed by gross domestic product (GDP). The relationship displayed by the environmental Kuznets curve partially confirms the above statement. In view of today's strong interest in environmental protection problems, the relationship defined by the environmental Kuznets curve is worth verifying.

The purpose of the research is to design a synthetic measure of the quality of the environment and specify the relation of this measure to gross domestic product, and furthermore to identify the impact of variables representing the quality of the environment on the value of the quality of the environment measure. The analysis covered data from 25 European Union countries in the years 2004-2016. The synthetic measure of the quality of the environment was designed using the TOPSIS-CRITIC method.

The result of the analyses is ascertainment of modification of the Kuznets curve, understood as the relationship between GDP and the quality of the environment. It was found that the Kuznets curve assumed a U-like shape in both classes of the analysed countries (growth and decrease of the geometric mean of the synthetic measure of the quality of the environment).
\end{abstract}

Key words: Kuznets curve, GDP, TOPSIS-CRITIC.

JEL code: A10, E01, O13, Q51.

\section{Introduction}

The quality of the environment is a very important element of sustainable development, next to economic, social and environmental factors (Soliwoda, 2015). A lot of factors shaping the quality of the environment are difficult to express in quantitative terms. Furthermore, the multitude of variables determining the quality of the environment makes it difficult to assess its real value. Therefore, an attempt to create a synthetic measure defining the quality of the environment was made. Application of a synthetic measure facilitates comparing units, especially if they are in large numbers, and allows for grouping units characterised by similar determinants (Majchrzak, Wysocki, 2007).

In literature there is a common view that environmental degradation increases along with GDP growth until the latter reaches a certain value after which the condition of the environment improves. This correlation is known as the Kuznets curve (Dinda, 2004). The environmental variation of the Kuznets curve was developed by Grossman and Krueger (Grossman, Krueger, 1991).

The environmental Kuznets curve shows the relationship between gross domestic product and the level of pollution of the environment, however, this concept does not take into consideration social impact, promotion of pro-environmental activities and the volume of funding of environmental protection activities by government agencies. Thus, it should be assumed that the above-mentioned factors may modify the shape of the environmental Kuznets curve.

The purpose of this paper is to propose a method for designing a synthetic measure of the quality of the environment and to verify the law governing the Kuznets curve by testing the relationship between the proposed measure and gross domestic product.

Achievement of the said purpose should produce new insight about the measurement of the quality of the environment and verify the relationship between the values defined by the Kuznets curve. Additionally,

\footnotetext{
${ }^{1}$ Research funded by the National Science Centre as part of OPUS-13 project, agreement no. UMO-2017/25/B/HS4/00011.

2 Jan.Polcyn@pwsz.pila.pl

${ }^{3}$ Sebastian.Stepien@ue.poznan.pl
} 
achievement of this purpose should provide mechanisms for monitoring maintenance of the natural environment in proportion to economic growth.

A major disadvantage of the synthetic measure of the quality of the environment is concentration of the environmental policy on selected components of the measure, what causes divergence in the objectives of the environmental policy. For instance, the said measure may go down as a result of deterioration of air quality, while there may be the opposite effect as soil quality might have improved at the same time.

\section{Research methodology}

First, the variables defining the quality of the environment were selected. The values of the variables were obtained from the Eurostat database. The analysis covered data from 25 European Union member states in the years 2004-2016. Some countries were excluded from the analyses (Romania, Croatia, Bulgaria) due to incomplete data in the Eurostat database.

Then, a synthetic measure of the quality of the environment was developed by means of the TOPSIS method (Technique for Order Preference by Similarity to an Ideal Solution) (Wysocki, 2010). By analysing the literature, 9 variables were selected for formation of the synthetic measure: estimated soil erosion by water, consumption of inorganic fertilizers - nutrient: phosphorus, consumption of inorganic fertilizers nutrient: nitrogen, ammonia emissions from agriculture, greenhouse gas emissions: agriculture, air pollution (non-methane volatile organic compounds), air pollutants (particulates $<2.5 \mu \mathrm{m}$ ), air pollutants (particulates $<10 \mu \mathrm{m}$ ), population of endangered birds species and habitats.

The values included in the analysis were converted to a hectare of an area to ensure comparability of the analysed variables.

From among the set of variables acceptable for the formation of the synthetic measure of the quality of the environment, those variables which were characterised by sufficient level of the coefficient of variance and were not excessively correlated with other coefficients were selected. Correlation was assessed by means of a correlation matrix between the variables and then an invertible matrix. Next step was the analysis of the diagonal elements of the invertible matrix. It was established that values exceeding 10 determine improper condition number of the matrix and thus excessive correlation of a particular feature with the other features (Czyzewski, Kryszak, 2017). Therefore, from 6 to 8 variables were qualified for the formation of the synthetic measure of the quality of the environment, depending on the year covered by the analysis (Table 1 ).

At the next stage, the variables qualified for the synthetic measure of the quality of the environment were subjected to zero unitarization, and destimulants were converted into stimulants (all the variables save for the population of endangered bird species and habitats variable, which was classified as a stimulant). The unitarization was performed according to the following formulae:

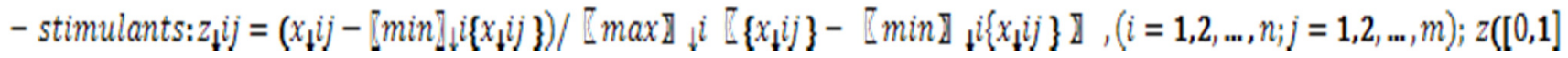

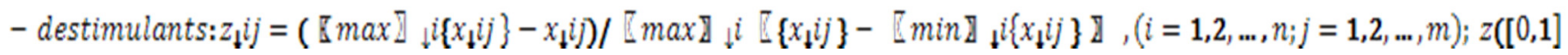

where: $\min _{i}\left\{x_{i j}\right\}-$ minimum value of $j$ feature, $\max _{i}\left\{x_{i k}\right\}$ - maximum value of $j$ feature, $i-$ object (in this case country).

Then, weights for particular coefficients were determined by means of the CRITIC method (Criteria Importance Through Intercriteria Correlation) (Diakoulaki et al., 1995; Deng et al., 2000). Similarly to the works of (Bieniasz et al., 2013; Czyzewski, Kryszak, 2017), an assumption that the influence of particular simple features on the value of synthetic measure of the quality of the environment is not identical was made. In the CRITIC method, weight coefficients are determined on the basis of standard deviations and correlation between the coefficients. A distinctive feature of this method is assigning relatively higher 
weights to features which are characterised by a high rate of variability and simultaneously low correlation with other features. The weight coefficients were determined according to the following formulae:

$$
w_{j}=\frac{c_{j}}{\sum_{k=1}^{m} c_{k}}, j=1,2, \ldots, m ; c_{j}=s_{j(z)} \sum_{k=1}^{m} \llbracket\left(1-r_{i j} \rrbracket\right), j=1,2, \ldots, m
$$

where: $c_{j}$ - measure of informational capacity of $j$ feature, $s_{j(z)}-$ standard deviation calculated out of the standardised values of $j$ feature, $r_{i j}$ - correlation coefficient between $j$ and $k$ features. The sum of the coefficients is 1 . Next step was multiplication of the determined standardised values of simple features by relevant weight coefficients.

At the next stage, calculation of Euclidean distances of particular units from the pattern and anti-pattern of development was performed. The calculation of Euclidean distances was performed according to the following formulae:

$$
\begin{aligned}
& d_{i}^{+}=\sqrt{\left(\sum_{j=1}^{k} \llbracket\left(z_{i j}^{*} \rrbracket\right)-z_{i j}^{+}\right)^{2}}-\text { distance from the pattern of development } \\
& d_{i}^{-}=\sqrt{\left(\sum_{j=1}^{k} \llbracket\left(z_{i j}^{*} \rrbracket\right)-z_{i j}^{-}\right)^{2}}-\text { distance from the anti - pattern of development }
\end{aligned}
$$

where:

$$
\begin{aligned}
& z_{j}^{+}=\left(\max \left(z_{i 1}^{*}\right), \max \left(z_{i 2}^{*}\right), \ldots, \max \left(z_{i k}^{*}\right)\right)=\left(z_{1}^{+}, z_{2}^{+}, \ldots, z_{k}^{+}\right) \\
& z_{j}^{-}=\left(\min \left(z_{i 1}^{*}\right), \min \left(z_{i 2}^{*}\right), \ldots, \min \left(z_{i k}^{*}\right)\right)=\left(z_{1}^{-}, z_{2}^{-}, \ldots, z_{k}^{-}\right)
\end{aligned}
$$

At the next stage, the value of $\mathrm{q}_{1}$ synthetic feature was determined according to the following formula:

$$
q_{i}=\frac{d_{i}^{-}}{d_{i}^{+}+d_{i}^{-}},(i=1,2, \ldots, n)(6)
$$

At the end-stage of the analyses, the countries were divided into two classes, taking growth (class A) or decrease (class B) of the geometrical mean of the synthetic measure of the quality of the environment as the criterion.

\section{Research results and discussion}

The application of the CRITIC method enabled to determine the weights of the variables used for the designation of the synthetic measure, the weights assigned to the variables forming the synthetic measure are shown in Table 1 . The estimated soil erosion by water variable (approximately $20 \%$ ) followed by the nutrition - nitrogen variable (approximately $19 \%$ ) had the biggest average share in the synthetic measure. Furthermore, it should be noted that three from among the analysed variables formed part of the synthetic measure only in certain years, these are the ammonia emissions from agriculture, air pollution (nonmethane volatile organic compounds) and air pollutants (particulates $<2.5 \mu \mathrm{m}$ ) variables. The air pollutants (particulates $<10 \mu \mathrm{m}$ ) variable did not meet the criteria which would allow for its inclusion in the measure of the quality of the environment in any of the analysed years. 
Weights of the variables used in the formation of the synthetic measure of the quality of the environment *

\begin{tabular}{|c|c|c|c|c|c|c|c|c|c|c|}
\hline$\frac{0}{z}$ & 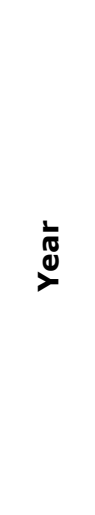 & 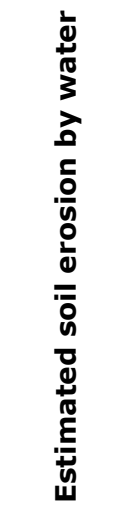 & 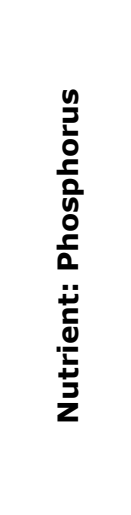 & 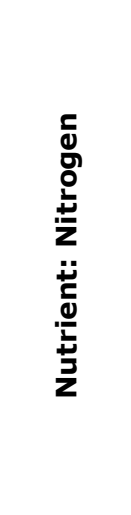 & 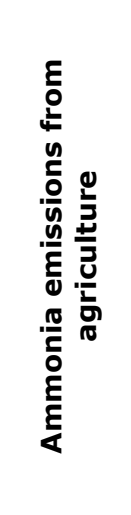 & 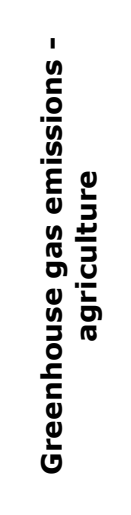 & 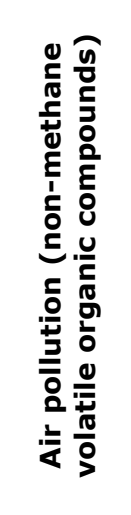 & 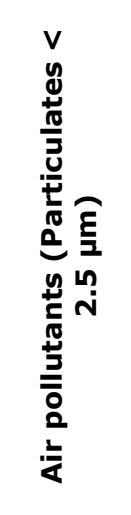 & 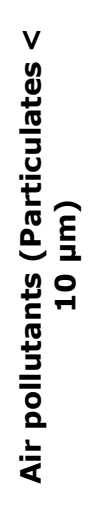 & 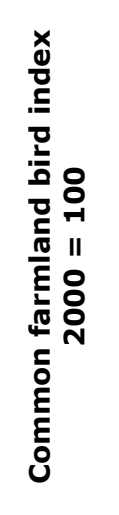 \\
\hline 1. & 2004 & 0.2173 & 0.1891 & 0.1784 & - & 0.1443 & 0.1285 & - & - & 0.1424 \\
\hline 2. & 2005 & 0.2168 & 0.1679 & 0.1811 & - & 0.1434 & 0.1227 & - & - & 0.1682 \\
\hline 3. & 2006 & 0.2200 & 0.1780 & 0.1699 & - & 0.1437 & 0.1253 & - & - & 0.1631 \\
\hline 4. & 2007 & 0.2222 & 0.1763 & 0.1693 & - & 0.1451 & 0.1292 & - & - & 0.1579 \\
\hline 5. & 2008 & 0.2026 & 0.1732 & 0.2074 & - & 0.1479 & - & 0.1200 & - & 0.1489 \\
\hline 6. & 2009 & 0.2093 & 0.1286 & 0.1654 & 0.0717 & 0.1075 & - & 0.1629 & - & 0.1545 \\
\hline 7. & 2010 & 0.1968 & 0.1496 & 0.2048 & 0.0972 & 0.1150 & - & 0.1027 & - & 0.1337 \\
\hline 8. & 2011 & 0.1979 & 0.1659 & 0.2227 & - & 0.1514 & - & 0.1182 & - & 0.1439 \\
\hline 9. & 2012 & 0.2018 & 0.1618 & 0.2123 & - & 0.1571 & 0.1226 & - & - & 0.1443 \\
\hline 10. & 2013 & 0.1877 & 0.1698 & 0.1771 & 0.0974 & 0.1303 & - & 0.1004 & - & 0.1374 \\
\hline 11. & 2014 & 0.2021 & 0.1673 & 0.2055 & - & 0.1590 & - & 0.1273 & - & 0.1388 \\
\hline 12. & 2015 & 0.1931 & 0.1612 & 0.1628 & 0.1206 & 0.1220 & - & 0.1082 & - & 0.1320 \\
\hline 13. & 2016 & 0.1745 & 0.1543 & 0.1493 & 0.1107 & 0.1072 & 0.0894 & 0.0915 & - & 0.1231 \\
\hline \multicolumn{2}{|c|}{ Mean } & 0.2008 & 0.1624 & 0.1860 & 0.0995 & 0.1352 & 0.1169 & 0.1164 & - & 0.1436 \\
\hline
\end{tabular}

The analyses carried out by Jankowska on a sample of 29 countries demonstrated that the environmental Kuznets curve assumed an N-like shape. The research covered the years 2000-2001 (Jankowska, 2016). The analyses conducted in this paper were based on the classification of the analysed EU countries (25) into two groups, one group consisted of countries showing average geometric growth of the synthetic measure of the quality of the environment (Figure 1). In the said group of countries, the Kuznets curve partially assumes a $U$-like shape $\left(R^{2}=0.2638\right)$, what is inconsistent with the model presentation of the Kuznets curve, as it assumes the shape of an inverted parabola in the models. In addition, it should be noted that the said curve is to a certain extent similar to the curve showing the relationship between the levels of air particulate pollutants and GDP (Grossman, Krueger, 1991).

The same curve shape as in the model defined as the Kuznets curve was obtained in the analysis of the relationship between economic growth, energy consumption and environmental protection quality in 11 countries in the years 1997-2013 (Destek, Sarkodie, 2019). Similar relations, characteristic of the model Kuznets curve, were obtained in other research focusing on the relationship between GDP level and carbon dioxide emission (Dong et al., 2019). 


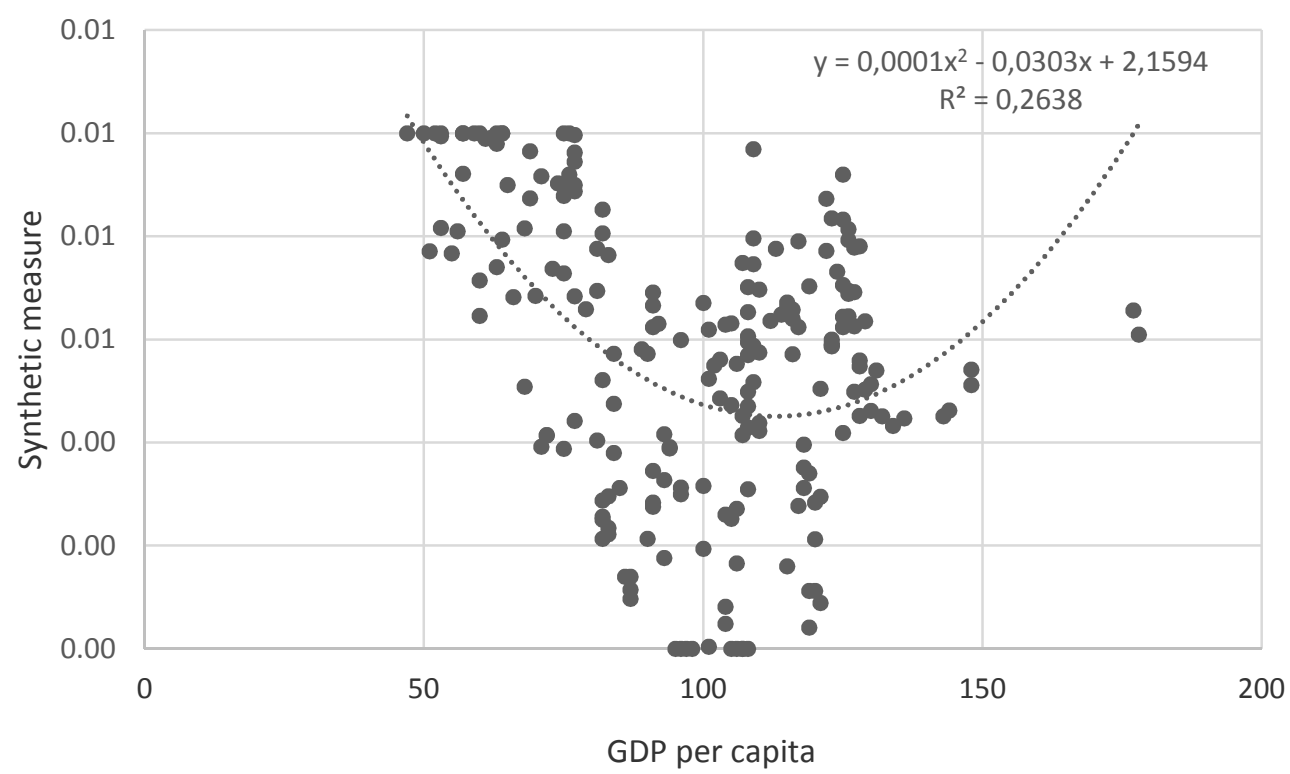

Fig. 1. Relationship between GDP per capita and the synthetic measure of the quality of the environment (countries showing growth of the geometric mean of the synthetic measure of the environment)

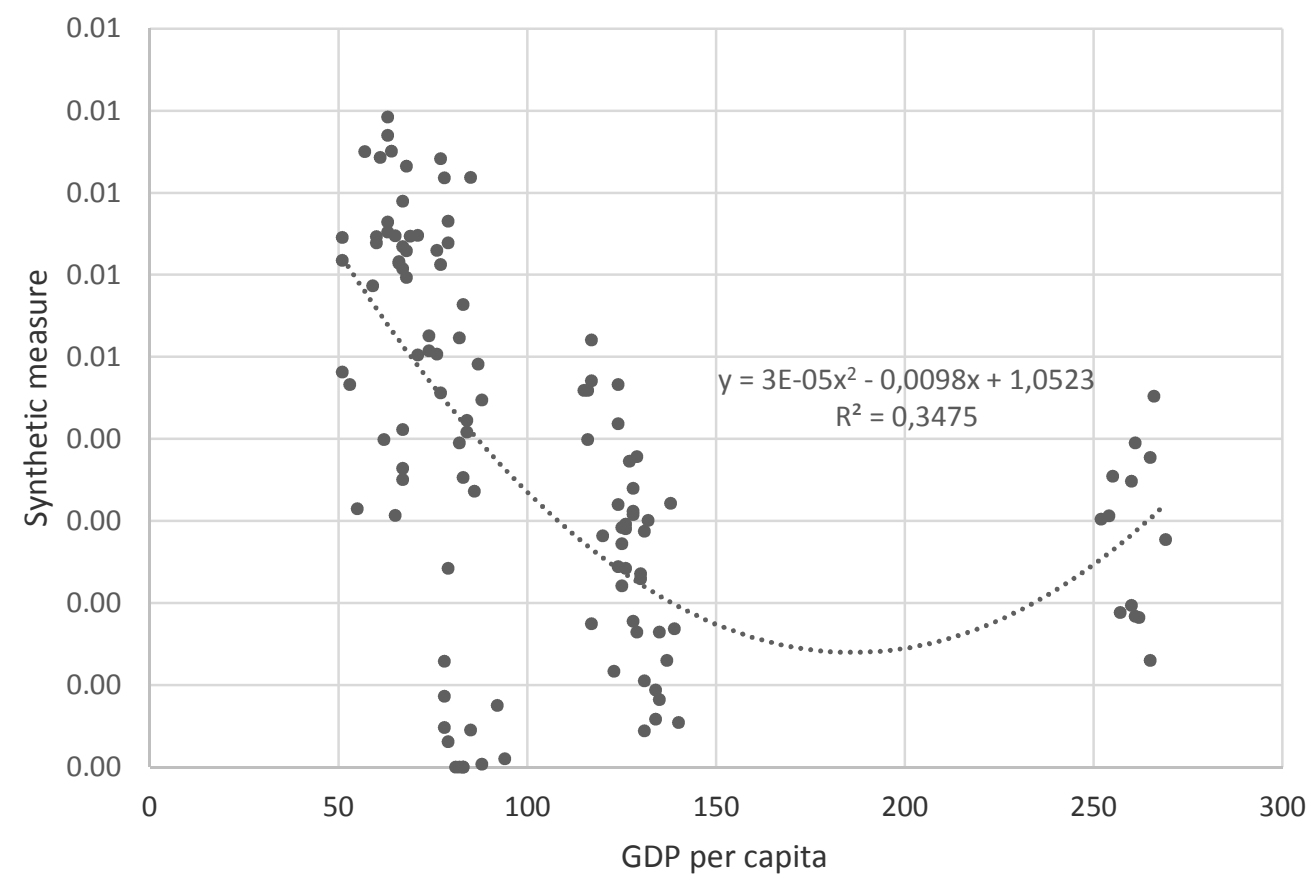

Fig. 2. Relationship between GDP per capita and the synthetic measure of the quality of the environment (countries showing decrease of the geometric mean of the synthetic measure of the environment)

The analyses carried out among the countries showing the decrease of the geometric mean of the synthetic measure of the quality of the environment produced a Kuznets curve with its shape remarkably similar to letter $U\left(R^{2}=0.3475\right)$. This result differs from the findings of Jankowska's analyses, where the curve assumed an $\mathrm{N}$-like shape (Jankowska, 2016).

In the analysed collective, 16 countries displayed an upward tendency and 9 countries showed a downward tendency displayed by the measure of the quality of the environment (Figure 3). It is therefore interesting to explain which variables and to what extent had impact on these tendencies in the pattern of the said measure. 


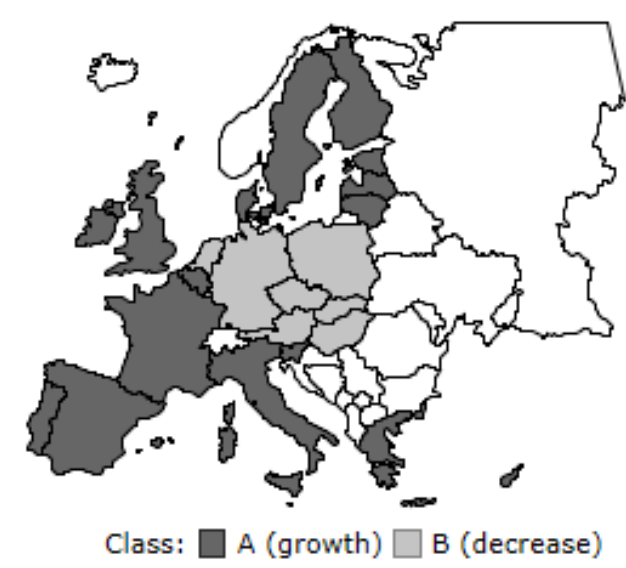

Fig. 3. Classification of the countries according to the direction (A - growth, B - decrease) of the average annual changes in the quality of the environment in the period 2004-2016

A very interesting relationship can be observed in terms of the location of the analysed countries by groups, i.e. class A - countries showing growth, class B - countries showing decrease of the geometric mean of the measurement of the quality of the environment (Figure 3). It should be noted that 8 out of 9 countries showing decrease of the geometric mean of the measure of the quality of the environment border each other, creating a distinctive territorial block. This location of the countries may suggest a similar level of intensification of agriculture, as the variables used in the formation of the synthetic measure of the quality of the environment are largely connected with agriculture. Another cause may be outsourcing of toxic production to class B countries, including branches of agriculture which produce negative effects on the environment (Kim, 2019).

The analysis of the dynamics of the changes in the measure of the quality of the environment expressed by geometrical mean in the entire analysed period, i.e. in the years 2004-2016, indicated constant trends. However, it should be remarked that despite the fact that these trends were constant, they developed differently among the countries showing growth of the geometric mean (Figure 4) from among the countries showing decrease of the said value (Figure 5).

The analysis of the values forming the synthetic measure of the quality of the environment for the two groups of countries shows considerable differences in particular in terms of nitrogen fertilization, ammonia emissions from agriculture, greenhouse gas emissions from agriculture, and air pollutants (Table 2).

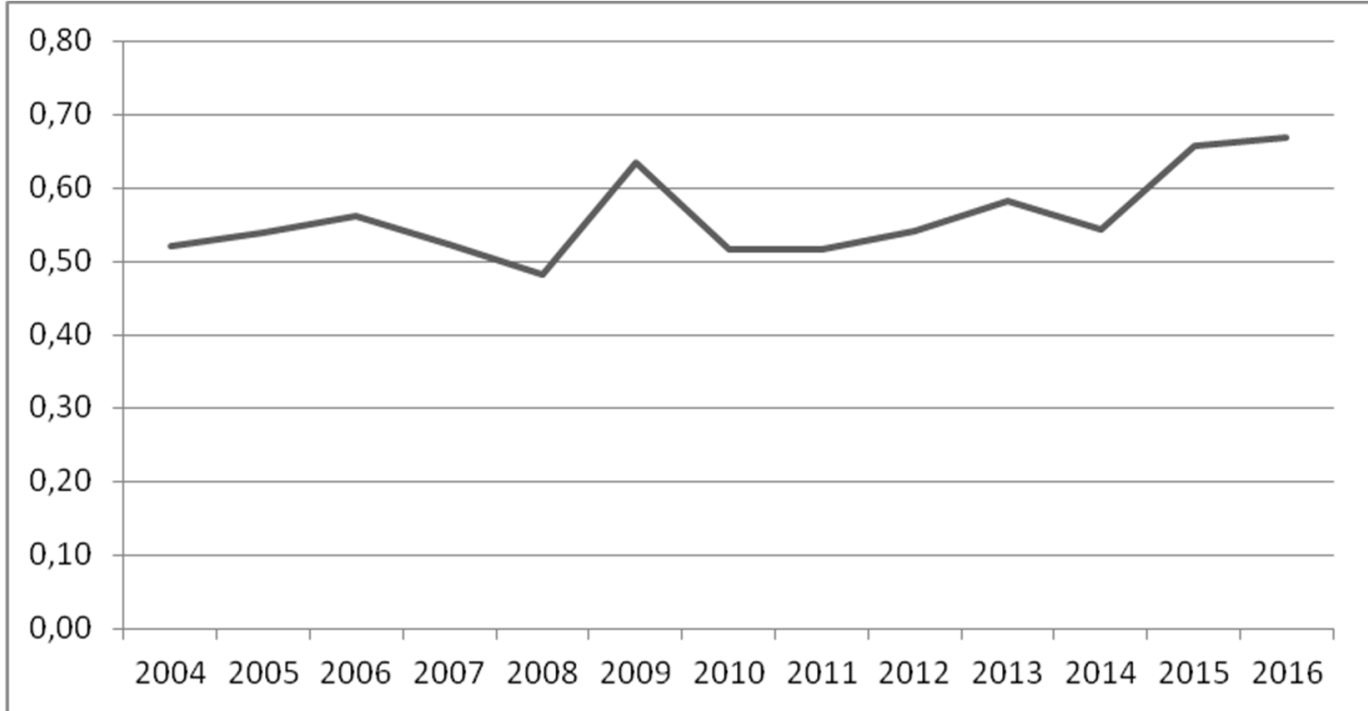

Fig. 4. Dynamics of the synthetic measure of environmental quality for the average value in countries with the geometric mean value of the analysed measure $<1$, in 2004-2016 


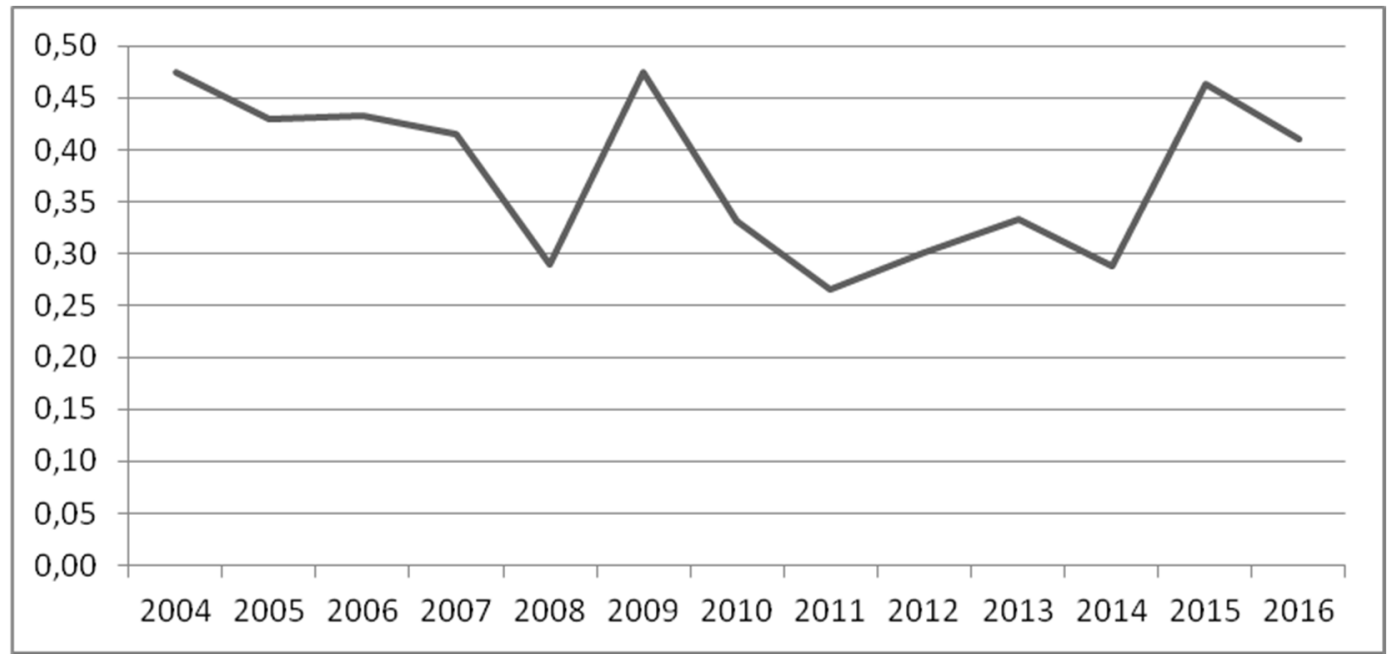

Fig. 5. Dynamics of the synthetic measure of environmental quality for the average value in countries with the geometric mean value of the analysed measure $>=1$, in the years 2004-2016

\section{Mean values of the variables forming the synthetic measure of the quality of the environment (years 2004-2016)}

\begin{tabular}{|c|c|c|c|c|c|}
\hline \multirow{2}{*}{ Class** } & \multicolumn{5}{|c|}{ Variable* } \\
\cline { 2 - 5 } & $\mathbf{x 1}$ & $\mathbf{x 2}$ & $\mathbf{x 3}$ & $\mathbf{x 4}$ & $\mathbf{x 5}$ \\
\hline A & 2.341 & 6.353 & 54.439 & 20.004 & 2942.116 \\
\hline B & 2.566 & 5.846 & 78.918 & 40.955 & 4058.424 \\
\hline Mean & 2.422 & 6.170 & 63.251 & 27.546 & 3343.987 \\
\hline A & $\mathbf{x 6}$ & $\mathbf{x 7}$ & $\mathbf{x 8}$ & $\mathbf{x 9}$ & \\
\hline B & 22.005 & 4.433 & 3.920 & 85.349 & \\
\hline Mean & 65.513 & 10.514 & 22.267 & 84.615 & \\
\hline
\end{tabular}

$* x_{1}$-estimated soil erosion by water, $x_{2}$-nutrient: phosphorus, $x_{3}$-nutrient: nitrogen, $x_{4}$-ammonia emissions from agriculture, $x_{5}-$ greenhouse gas emissions - agriculture, $x_{6}$-air pollution (non-methane volatile organic compounds), $x_{7}$-air pollutants (Particulates < 2.5 $\mu \mathrm{m}), x_{8}$-air pollutants (Particulates $<10 \mu \mathrm{m}$ ), $x_{9}$-common farmland bird index $2000=100$,

$* *$ class $A$ - countries with the geometric mean of the synthetic measure of the quality of the environment $>=1$, class $B-$ countries with the geometric mean of the synthetic measure of the quality of the environment $<1$

\section{Conclusions}

1) Two dissimilar patterns of the Kuzents curve from the most common ones found in literature. The Kuznets curve assumed a U-like shape in both classes of the analysed countries.

It should be noted that the subject of the analysis was the relationship between gross domestic product and the synthetic measure of the quality of the environment, which is a completely different value from the values commonly used in the Kuznets curve. In the traditional environmental Kuznets curve, one value is always gross domestic product, but the other value frequently varies (Sarkodie, Strezov, 2019).

2) The present analyses refer to the area of the analysed territories. Further analyses should also focus on the population which plays a very important role in creating consumption adversely affecting the quality of the environment. Another major problem is analysing the values in relation to the structure of foreign trade to test exchange transactions between countries in terms of negative impact on the quality of the environment.

\section{Bibliography}

1. Bieniasz, A., Golas, Z., Łuczak, A. (2013). Zroznicowanie kondycji finansowej gospodarstw rolnych wyspecjalizowanych w chowie owiec i koz w krajach Unii Europejskiej (Diversity of the Financial Condition of Farms Specialising in Sheep and Goat Husbandry in the European Union countries). Roczniki Ekonomii Rolnictwa i Rozwoju Obszarow Wiejskich, 100 (1), 168-181.

2. Czyzewski, B., Kryszak, L. (2017). Kondycja finansowa gospodarstw rolnych w regionach FADN Unii Europejskiej i jej zwiazek z produktywnoscia czynnikow wytworczych (Financial Condition of Agricultural Holdings in EU FADN 
Regions and its Relation to Factor Productivity). Roczniki Naukowe Ekonomii Rolnictwa i Rozwoju Obszarow Wiejskich, 104 (3), 7-20.

3. Deng, H., Yeh, C. H., Willis, R. J. (2000). Inter-company Comparison Using Modified TOPSIS with Objective Weights. Computers \& Operations Research, 27, 963-973.

4. Destek, M. A., Sarkodie, S. A. (2019). Investigation of Environmental Kuznets Curve for Ecological Footprint: The Role of Energy and Financial Development. Science of the Total Environment, 650, 2483-2489.

5. Diakoulaki, D., Mavrotas, G., Papayannakis, L. (1995). Determining Objective Weights in Multiple Criteria Problems - the Critic Method. Computers \& Operations Research, 22, 763-770.

6. Dinda, S. (2004). Environmental Kuznets Curve hypothesis: A survey. Ecological Economics, 49, 431-455.

7. Dong, F., Wang, Y., Su, B., Hua, Y. F., Zhang, Y. Q. (2019). The process of peak CO2 emissions in developed economies: A perspective of industrialization and urbanization. Resources Conservation and Recycling, 141, 61-75.

8. Grossman, G. M., Krueger, A. B. (1991). Environmental Impacts of a North American Free Trade Agreement. NBER Working Paper No. 3914.

9. Jankowska, E. (2016). Srodowiskowa krzywa Kuznetsa w dekarbonizacji europejskich gospodarek (Environmental Kuznets Curve in Decarbonisation of the European Economics). Studia Ekonomiczne. Zeszyty Naukowe Uniwersytetu Ekonomicznego w Katowicach, 289, 51-61.

10. Kim, S. (2019). CO2 Emissions, Foreign Direct Investments, Energy Consumption, and GDP in Developing Countries: A More Comprehensive Study using Panel Vector Error Correction Model. Korean Economic Review, 35, $5-24$.

11. Majchrzak, A., Wysocki, F. (2007). Potencjal produkcyjny rolnictwa w wojewodztwie wielkopolskim (Productive Potential of Agriculture in Greater Poland Province). Roczniki Naukowe Stowarzyszenia Ekonomistow Rolnictwa $i$ Agrobiznesu, 9 (2), 217-221.

12. Sarkodie, S. A., Strezov, V. (2019). A Review on Environmental Kuznets Curve Hypothesis Using Bibliometric and Meta-Analysis. Science of the Total Environment, 649, 128-145.

13. Soliwoda, M. (2015). Dylematy wokol wymiaru finansowego zrownowazenia gospodarstw rolniczych (Dilemmas in a Financial Dimension of Sustainability of Farms). Zagadnienia Ekonomiki Rolnej, 344 (3).

14. Wysocki, F. (2010). Metody taksonomiczne w rozpoznawaniu typow ekonomicznych rolnictwa i obszarow wiejskich (Taxonomic Methods in Recognising Economic Types of Agriculture and Rural Areas), Poznan, Wydawnictwo Uniwersytetu Przyrodniczego w Poznaniu. 